\title{
WORK READINESS REVIEWED FROM LEARNING ACHIEVEMENT OF COMPUTER ACCOUNTING SUBJECT, CAREER GUIDANCE, AND WORK MOTIVATION OF CLASS XII STUDENTS ACCOUNTING SKILL PROGRAM OF SMK NEGERI 1 SUBOH SITUBONDO
}

\author{
Wiwin Kusbiyantari ${ }^{1}$ \\ Hari Sukarno ${ }^{2}$ \\ Yuniorita Indah Handayani ${ }^{3}$
}

\author{
Higher Education of Economic Mandala \\ e-mail: refaaura@yahoo.com
}

\begin{abstract}
The purposes of this study are: 1) To analyze the influence of learning achievement of computer accounting subject, career guidance and work motivation partially to the work readiness. 2) To study the influence of learning achievement computer accounting subject, career guidance and work motivation simultaneously to the work readiness. The samples in this study were the students of class XII Accounting skill program of SMK Negeri 1 Suboh Situbondo which amounted to 55 people. This research includes the type of explanatory research. Independent variables of this study are learning achievement of computer accounting subject (PB), career guidance (BK) and work motivation (MK) while dependent variable is work readiness (KK). Data analysis used is test of validity and reliability, multiple linear regression analysis, classical assumption test and hypothesis test. Regression analysis results obtained equation of regression line. This can be seen from the linear regression equation as follows $\mathrm{KK}=20,774+0,505 \mathrm{~PB}+0,344 \mathrm{BK}+0,283 \mathrm{MK}$. The equation indicates that readiness of work influenced by learning achievement of computer accounting subject, career guidance and work motivation. The conclusions are: 1) learning achievement of computer accounting subject, career guidance and work motivation partially significant effect on the work readiness of class XII students accounting skill program in SMK Negeri 1 Suboh Situbondo. 2). Learning achievement of computer accounting subject, career guidance and work motivation simultaneously have a significant effect on the work readiness of class XII students accounting skill program at SMK Negeri 1 Suboh Situbondo.
\end{abstract}

Keywords: learning achievement, career guidance, work motivation and work readiness

\section{INTRODUCTION}

Education is one way in order to prepare qualified and professional resources. Education can be pursued through formal, non-formal and informal channels which takes place in accordance with the applicable rules. Vocational High School (SMK) is one of the formal education paths that intends to prepare the needs of middle-level workers who have the knowledge, skills and work attitude in accordance with the needs of employment.

The readiness of work is influenced by many factors. According to Winkel and Hastuti (2007: 647) and Sukardi (1993: 44) the factors that affect the readiness of work consists of 2 factors: internal and external. Measurement accomplishment of student achievement in mastering computer accounting program from practice and theory can be seen from 
student achievement. Student achievement is the mastery of knowledge or skills developed by the subject, usually indicated by the value of the test or the value given by the teacher (Tu'u, 2004: 65).

Factors of knowledge about the fields of work and about themselves obtained through the guidance of teachers, are factors that can affect the readiness of students' work (Winkel and Hastuti, (2007: 652). The career guidance is the process of providing assistance to students in understanding and doing the basis of selfknowledge and recognition of employment opportunities as well as the ability to take decisions so that students can manage the development of his career. In addition, there is a need to encourage more learners to work in. Encouragement and insistence from the surrounding environment either from the school environment, family environment, and community environment will provide motivation to learners to enter the workforce.

Readiness can be interpreted as the overall condition of a person that keeps students ready to respond or take action in a certain way to the situation and conditions underway (Ali and Akbar, 2013). Meanwhile, according Slameto (2010: 113) readiness is whole condition of someone who makes it ready to respond or answer in a particular way toward a situation. While Dalyono (2005: 166) states that readiness is the nature and personal strength of a developing person, which allows the person can adjust to the environment and be able to solve the problems he faces.

Work is the essence of human life. As long as human lives, they must always work to meet the needs of life. Thus it can be said that in humans there are needs that by the time it forms the goals to be achieved and fulfilled. To achieve those goals, People are encouraged to do activities called work (Anoraga, 2005: 11). While according to Djaali (2008: 113) work is a form of activity that aims to obtain satisfaction.
Work readiness is the main capital for students to do the job, so that with the readiness of work they will obtain maximum results. According to Wagner in Paradise (2012) work readiness is a set of skills and behaviors needed to work in any job shape. So the readiness of work is the overall condition of the individual to provide responses or answers in certain situations such as practicing the knowledge, comprehension, and skills possessed to perform a job in order to meet his needs.

According to Tu'u (2004: 75) learning achievement is the mastery of knowledge or skills developed by the subject, usually indicated by the value of tests or score values provided by the teachers. Syah (2010: 139) explained that the achievement of learning is the level of student success in achieving the objectives set out in a program. Learning achievement is a combination of learning outcomes, where the learning outcomes of some basic competencies are then tested. Student learning achievement is evidenced and demonstrated through the scores or values of the results of evaluations made by teachers on student and repetitive. Student achievement learning is evidenced and shown through the score or value of the results of evaluations made by the teacher to the student's assignment repeatedly or the test he took.

Guidance is the help or support given to the individual or group of individuals in avoiding or overcoming difficulties in his life, so that the individual or group of individuals can attain the welfare of their lives (Walgito, 2005: 5-6). Meanwhile, according to Sukardi (2008: 36) guidance can be interpreted as a process of providing assistance to individuals who are done on an ongoing basis so that the individual can understand himself, so he is able to enforce himself and can act fairly, in accordance with the demands and circumstances of the school environment, family, and community and life in general. Jobs by Murray in 
Supriatna and Ilfiandra (2006) is a range of work activities that are interconnected, in this case a person advancing life by involving a wide range of behaviors, skills, attitudes, needs, aspirations, and ideals as the span of his own life.

Career guidance is essentially one of the educational endeavors through personal approaching education in helping individuals to achieve the necessary competition in the face of career problems. Career guidance is a service provided to learners to make career plans and prepare for work life. Through the activities of career guidance of students equipped and trained with various activities related to the what, why and how to plan a future, meaning that the students ranging from grade one to finish vocational training, guided to the activities related to how to plan carrier throughout life (career life span)

Someone will work happily if what he performs is according to his condition, according to his ability and along with his interests (Walgito, 2005: 194). So career guidance is a service provided to learners to devise a career plan and prepare for work life.

Motivation of work according to Anoraga (2005: 34) is something that raises the spirit or the drive of work. Everyone has different motivations to fulfill what they want to achieve. Strong and weak work motivation of a workforce, participate determine the size of his achievements.

According Purwanto (2007: 73) motivation is a conscious effort to move, direct, and maintain a person's behavior so that he encouraged to act of doing something to achieve a certain result or goal. According to Uno (2011: 11) motivation is an impulse arising from the stimulation from within and from outside so that someone wants to make a certain behavior change / activity better than the previous state. Based on the opinions of experts above motivation is a good impulse from within and outside himself to perform an action for the achievement of personal goals of each individual. So work motivation is something that raises the spirit or encouragement of students to enter the world of work. The impulse comes from within themselves and from outside himself.

Work readiness is a thing that can be formed and studied, so it can be cultivated achievement either through education, training and so forth. SMK as a formal secondary education institution that is specifically aimed at preparing its students to work in a certain field has a very important role in printing candidates of middle-level workers with standardized competence in accordance with work competency standards.

To achieve these goals, SMK students are given productive subject of accounting. Productive subjects are a group of subjects that serve to equip learners to have the competence of work appropriate with SKKNI (Dikmenjur, 2006). Productive subjects serve as a vocational support component that basically contains knowledge, attitudes and skills related to their field of specialization as well as the content of learning of this component in the form of applied knowledge, which can be used as a basis in learning the skills. One of the productive subjects that should be mastered by vocational students is the subject of computer accounting.

Computer accounting is one of the material of accounting practice as a balancer of current technological developments introduced when the students of class XI. Learning achievement is one benchmark in knowing the extent to which students can digest the entire subjects being taught. The indicator used is the final exam (UAS) value of computer accounting subject. With a good accounting learning achievement, it will further support students in getting jobs in the field of Accounting, so they will feel 
much better prepared when they enter this field.

To improve students' work readiness, school also provides counseling services in the form of career guidance. According to Walgito (2005: 194) career guidance is the guidance given to a person to work well, with pleasure, diligently tailored to the demands of the job or job with what is within the individual concerned. Career guidance conducted in the school aims to enable students to develop their own attitudes and values in the face of employment and in preparation for entry. Career guidance is intended to assist in career planning, decision-making, skills development or expertise, career information and self-understanding. Students who get adequate career guidance in their schools will have more readiness in the world of work.

In preparing the students' work preparation hours that has been delivered above should also be raised encouragement from students themselves about willingness to move through work motivation. Motivation is a work that raises the spirit or encouragement of individuals to enter the world of work, both from within themselves and from outside of they themselves. It is said in Anoraga (2006: 26) that "success in work is very dependent on motivation, sincerity, discipline and work skills". With the motivation of work within the students, then consciously and without coercion of the students will be able to produce something better in order to achieve its goal to get the job they want, so that motivation work here can improve the readiness of students in the business / industry.

Based on the description that has been described above, it can be described conceptual framework model in this study as in the following picture:

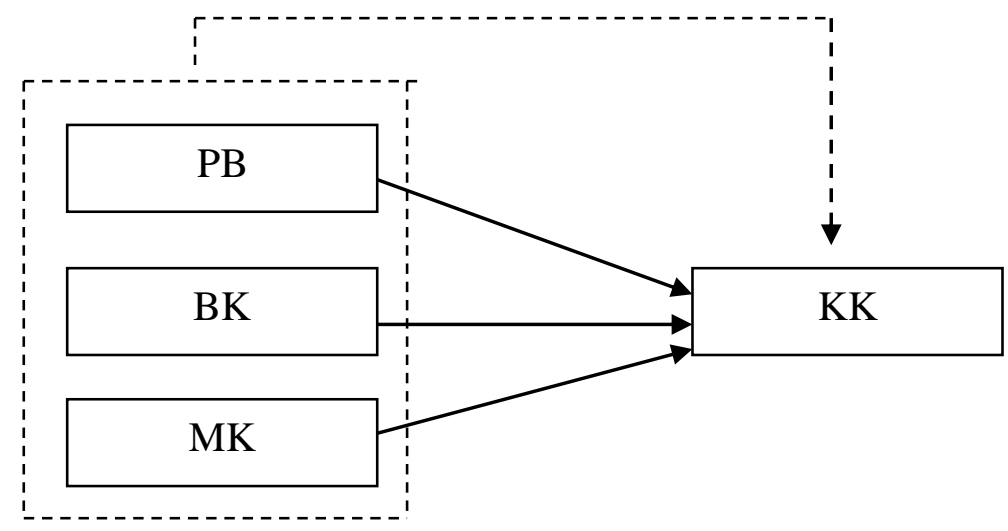

Captions:

$\mathrm{PB}=$ Achievement Subject of Computer Accounting

BK = Career Guidance

MK = Work Motivation

$\mathrm{KK}=$ Work Readiness

$---\rightarrow=$ Simultaneous

$\longrightarrow=$ Partial

\section{Hypothesis}

1. There is influence of learning achievement of computer accounting subject, career guidance and work motivation partially to student working readiness

2 There is influence of learning achievement of computer accounting subject, career guidance and work 
motivation simultaneously to student working readiness

\section{RESEARCH METHODS}

This research was a kind of explanatory research. The location of this research was at SMK Negeri 1 Suboh Situbondo, Jalan Raya Suboh No 03, Suboh District, Situbondo Regency, East Java. The population in this study was the students of class XII Accounting Skill Program of SMK Negeri 1 Suboh Situbondo. In this study there was no need to use sampling technique because there was no difficulty in collecting data with the population to be studied and information obtained by using the census method. The variables to be analyzed in this study were grouped into two independent variables consisting of Achievement Learning Subject Computer Accounting (PB), Career Guidance (BK), Work Motivation (MK) and the dependent variable is Work Readiness (KK).

Methods of data collection in this study used the method of documentation and questionnaire methods. While for data analysis method, this research used validity and reliability test, classical assumption test and multiple regression analysis with F-test and t-test.

In this study the regression model used can be seen as follows:

\section{$\beta 3 \mathrm{MK}$}

$$
\mathrm{KK}=\alpha+\beta 1 \mathrm{~PB}+\beta 2 \mathrm{BK}+
$$

The $\mathrm{t}$ test was used to determine the effect of each dependent variable (work readiness) on the independent variables used to measure the problem formulation to 1 . The use of significance levels in the $t$ test varies:
a. Ho: $b_{i}=0$
b. Ha: $b_{i} \neq 0$,
1. If the significance value $<0.05$ then Ho is rejected, meaning that it can be said there is a significant effect

partially between learning achievement of computer accounting subject, career guidance and motivation towards work readiness.

2. If the significance value $>0.05$ then Ho is accepted, meaning no significant effect partially between learning achievement of computer accounting subject, career guidance and motivation towards work readiness.

$F$ test was used to determine the effect of free variables simultaneously on the dependent variable. Significant means the relationships that occur can apply to the population. The use of significance levels in the $\mathrm{F}$ test varies:

a. Ho: $b_{i}=0$

b. Ha: one $b_{i} \neq 0$,

1. If the significance value $<0.05$ then Ho is rejected, meaning that it can be said there is a significant influence jointly amongs learning achievement of computer accounting subject, career guidance and motivation towards work readiness.

2. If the significance value $>0.05$, then Ho is accepted with no significant effect jointly between the learning achievement of computer accounting subject, career guidance and motivation towards work readiness.

\section{RESULTS ANALYSIS}

The calculation result of multiple linear regression analysis in this study with the help of a computer calculation program Statistical Product and Service Solutions (SPSS) version 19.0. The recapitulation of the results of multiple linear regression analysis is presented in Table 1.

Based on the result of multiple linear regression analysis, it was obtained regression equation as follows:

$\mathrm{KK}=20,774+0,505 \mathrm{~PB}+0,344 \mathrm{BK}+$ 0,283 MK 
Table Recapitulation of Results of Multiple Linear Regression Analysis

\begin{tabular}{|l|l|l|l|l|l|}
\hline \multirow{2}{*}{ No. } & \multirow{2}{*}{ Free Variable } & Regression & Presentation & of \\
hypotheses & Sign. \\
\cline { 4 - 5 } & & & T-count & T-table & \\
\hline 1. & Learning Achievement $(\mathrm{PB})$ & 0.505 & 3,653 & 2,008 & 0.001 \\
\hline 2. & Career guidance $(\mathrm{BK})$ & 0.344 & 2,390 & & 0.021 \\
\hline 3. & Work Motivation $(\mathrm{MK})$ & 0.283 & 2,362 & & 0.022 \\
\hline Constants & $=20,774$ & & \\
\hline $\mathrm{R}^{2}$ & $=0.451$ & & \\
\hline F-count & $=13.971$ & \\
\hline F-table $(5 \% ; 3.51)$ & $=2.786$ & \\
\hline Significance & $=0,000$ & \\
\hline
\end{tabular}

Table Recapitulation of Test Results $t$

\begin{tabular}{|l|l|l|l|}
\hline Variable & T-count & T-table & Sig. \\
\hline Learning Achievement (PB) & 3,653 & 2,008 & 0.001 \\
\hline Career guidance (BK) & 2,390 & & 0.021 \\
\hline Work motivation $(\mathrm{KK})$ & 2,362 & & 0.022 \\
\hline
\end{tabular}

Based on t test steps and table 2, then hypothesis testing for each independent variable of learning achievement, career guidance and work motivation to work readiness are as follows:

1) Learning Achievement Variable (PB)

Based on table 2, the significance value on learning achievement variable is 0.001 . So the significance value is less than 0.05 or $0.001<0.05$. This shows that the variable of learning achievement of computer accounting subject partially have a significant influence on the work readiness.

2) Variable Career Guidance (BK)

Based on table 2, the significance value in career guidance variable is 0.021 . So the significance value is less than 0.05 or $0.021<0.05$. This shows that the variable of career guidance partially have a significant influence on the readiness of work.

3) Variables Motivation work (MK)
Based on table 2, the significance value in the variable work motivation is 0.022 . So the significance value is less than 0.05 or $0.022<0.05$. This shows that the variable of work motivation partially have a significant influence on the readiness of work.

Based on Table 1, the significance value of learning achievement variable of computer accounting, career guidance and work motivation is 0.000 . So the significance value is less than 0.05 or $0.000<0.05$. It shows that simultaneously variable of learning achievement of computer accounting subject, career guidance and work motivation have significant influence to performance, hence Ho is rejected.

\section{CONCLUSIONS, IMPLICATIONS AND SUGGESTIONS}

Based on the results and discussion about the influence of learning achievement of computer accounting subject, career guidance and work 
motivation on job readiness in SMK Negeri 1 Suboh Situbondo, it can be concluded that learning achievement of computer accounting subject, career guidance and work motivation were affected partially on work readiness toward class XII students of accounting skill program of SMK Negeri 1 Suboh Situbondo and learning achievement of computer accounting subject, career guidance and work motivation simultaneously have a significant effect on work readiness toward class XII students of accounting skill program of SMK Negeri 1 Suboh Situbondo.

While the implications of this research is to improve work readiness, learning achievement, career guidance and work motivation should be balanced and should be improved as well. This is in accordance with the concept of human resource development.

Based on the results of research and conclusions, it can be submitted some suggestions that can be expected beneficial for practical interests and benefit further among others. The school should make students ready to enter the world of work or cooperate with partner agencies and other agencies in the distribution of graduates and for other researchers Which relates to this research are still open opportunities to add variables, develop models in different situations by expanding the number of samples and research sites, so that generalizations can be broadened.

\section{REFERENCES}

Alfan, Muhammad Zachim. Pengaruh Bimbingan Karier dan Lingkungan Sekolah Melalui Motivasi Kerja Terhadap Kesiapan Kerja Siswa Kelas XIIkompetensi Keahlian Akuntansi SMK Negeri 2 Magelang. Dalam Economic Education Analysis Journal Vol. 3 No. 1

Anoraga, Pandji. 2005. Psikologi Kerja.
Jakarta : PT Rineka Cipta

Boulianne, Emilio. 2012. Impact of accounting software utilization on students' knowledge acquisition An important change in accounting education. Diunduh dari www.emeraldinsight.com/18325912.htm

Firdaus, Zamzam Zamawi. 2012. Pengaruh Unit Produksi, Prakerin Dan Dukungan Keluarga Terhadap Kesiapan Kerja Siswa SMK. Dalam Jurnal Pendidikan Vokasi. Vol. 2, No. 3.

Fitriyanto, Agus. 2006. Ketidakpastian Memasuki Dunia Kerja Karena Pendidikan. Jakarta : Rineka Cipta

Ghozali, Imam. 2011. Aplkasi Analisis Multivariate dengan Program IBM SPSS 19.Semarang : Badan Penerbit Universitas Diponegoro.

Harja, Iwan Riya. 2013. Pengaruh Kompetensi Kerja dan Motivasi KerjaTerhadap Kesiapan Kerja Siswa Kelas XII Program Studi Teknik Instalasi Tenaga Listrik SMK N 2 Yogyakarta. Jurnal Pendidikan Teknik.Yogyakarta: Fakultas Teknik Universitas Negeri Yogyakarta (eprints.uny.ac.id ). http://bps.go.id/pengangguranterbuka/.

Peraturan Pemerintah Republik Indonesia Nomor 17 Tahun 2010 tentang Pengelolaan dan Penyelenggaraan Pendidiksan. www.kemdiknas.go.id (

Peraturan Pemerintah No. 70 Tahun 2013 Tentang Kerangka Dasar Dan Struktur Kurikulum Sekolah Menengah Kejuruan/Madrasah Aliyah Kejuruan. http://bsnpindonesia.org/id/? $\mathrm{p}=1239$

Purwanto, M. Ngalim. 2007. Psikologi Pendidikan. Bandung : PT Remaja Rosdakarya

Sardiman. 2011. Interaksi dan motivasi belajar mengajar. Jakarta : PT. Raja Grafindo Persada

Slameto. 2010. Belajar dan Faktor-Faktor 
Yang Mempengaruhinya. Jakarta :

PT. Rineka Cipta

Sukardi, Dewa Ketut. 1993. Bimbingan

Karir di Sekolah-sekolah. Jakarta :

Ghalia Indonesia.2008. Pengantar

Pelaksanaan Program Bimbingan

dan Konseling di Sekolah.Jakarta :

PT Asdi Mahastaya

Syah, Muhibbin. 2010. Psikologi Pendidikan Dengan Pendekatan Baru. Bandung: PT. Remaja Rosdakarta

Tu'u, Tulus. 2004. Peran Disiplin Pada Perilaku dan Prestasi Siswa.Jakarta Grasindo.

Uno, Hamzah B. 2011.Teori Motivasi dan Pengukurannya. Jakarta: PT. Bumi Aksara

Valid, Yanuar Mipalas dan Abdullah Taman. 2012. Pengaruh Pengalaman Praktik Industry Dan Prestasi Belajar Terhadap Kesiapan Kerja SiswaKelas XI Program Keahlian Akuntansi SMK YPKK 2 SLEMAN YOGYAKARTA. Dalam Kajian Pendidikan Akuntansi Indonesia.Hal 161-183.

Winkel dan Hastuti. 2007. Bimbingan dan Konseling di Institusi Pendidikan. Yogyakarta : Media Abadi

Walgito, Bimo. 2005. Bimbingan dan Konseling. Yogyakarta : Andi 